\title{
Modelling the development of the Šibenik Urban Area (Croatia) according to the objectives of European green policies
}

Ivana KATURIĆ, PhD, Director, Urbanex / Lecturer, Faculty of Architecture - University of Zagreb, Croatia

Ivan ŠIŠAK, MSc, Consultant, Urbanex, Croatia

Mario GREGAR, MSc, Consultant, Urbanex, Croatia

\begin{abstract}
This paper presents a model of strategic development of the Šibenik Urban Area aligned with green development policies at EU level. This article discusses the concept of the European Green Deal as well as the needs and opportunities arising from it (green and energy transition), which are related to the development of urban areas, with the addition of Farm-to-Fork Strategy and the blue development concept. The research of statistic data and field interviews identified the potential of this area and clarified in the context of three spatial zones (coast, hinterland and island zone). For these three zones, development scenarios are given: Post-COVID Reactivation, Green Transition, Farm-to-Fork, Mobile Citizens and Blue Development. Paper emphasises importance of the European Green Deal in the context of post-COVID revitalisation and the possibility of applying a similar model of development in other European Mediterranean cities the concept of functional connection with the surrounding area.
\end{abstract}

\section{Keywords}

Šibenik, European Green Deal, strategic planning, urban areas, green transition

\section{Introduction}

The Law on Regional Development of the Republic of Croatia (OG 147/14; 123/17; 118/18) introduced for the first time the concept of urban areas into the regional development system of Croatia. In European literature, the visionaries of spatial and regional planning from the late $19^{\text {th }}$ century and the first half of the $20^{\text {th }}$ century (such as Ebenezer Howard, Patrick Geddes and Patrick Abercrombie) realized that in modern conditions it is impossible to separate the planning of the development of the city from the planning of its surroundings (Hall and Tewdwr-Jones, 2010), primarily because the population of the surrounding area uses the functions of the city (jobs, urban services, etc.), and the city uses the surrounding area to develop business, residential and recreational zones (Priebs, 2019). In Croatia, by establishing a spatial category of urban agglomerations (urban regions with a main city of more than 100,000 inhabitants) and urban areas (urban regions with a main city of between 10,000 and 100,000 inhabitants) in strategic planning, a step towards strengthening the cooperation of different spatial units in the creation and implementation of common development policies has been taken. In 2021, at the beginning of the new programming period of the European Union (EU), some Croatian cities were given the opportunity to combine their own development policies with the development policies of 
municipalities in their surroundings through ITI mechanism. One of them is Šibenik, which urban area includes three local self-government units (City of Šibenik, City of Skradin and Municipality of Bilice) with total population of about 50,000. Once an industrialized area, today is highly focused on tourism, which has suffered great loss during the global COVID-19 pandemic. For this reason, it is necessary to create a sustainable and resilient development of this area, which will be based on two fundamentals: green transition in accordance with the European Green Deal and the creation of uniform spatial development, triggering demographic revitalisation and economic diversification. This article analyses the policies of green development of the EU, explains the spatial characteristics of the Šibenik Urban Area and the state of its spatial and regional development based on qualitative research and interviews, proposes the scenario of the future development of the Šibenik Urban Area, and implies its applicability in other areas of Europe and the Mediterranean.

\section{European Green Deal - Green Urban Renewal}

The European Green Deal (COM(2019) 640) is a document highlighting the European Commission's intention to make Europe the first climate-neutral continent by 2050, which is intended to be achieved through adaptation of vital economic sectors, as well as through interventions in the social and urban environment. This plan was created to respond on climate change and provides guidelines for an overall transformation of Europe's social, economic and infrastructure environment with a departure from the previously implemented green growth policy, in which economic development was accompanied by green solutions, towards a policy in which climate protection becomes equally important as economic development (Ossewaarde and Ossewaarde-Lowtoo, 2020). The responsibility of urban and regional authorities in the $\mathrm{EU}$ is $70 \%$ of climate change mitigation activities and $90 \%$ of climate change adaptation activities (Abudllah, 2021). Therefore, aligning the development policy of cities in the EU and their urban environments with the European Green Deal is of paramount importance. However, the concrete and effective way in which cities will engage in the implementation of policies and objectives defined in the European Green Deal is yet to be devised (de Gregorio Hurtado, 2021). Nevertheless, it can be noted that the green transition of urban infrastructure is one of the most challenging activities of the urban component of the European Green Deal. European cities are expanding more slowly than those of developing countries and have therefore been able to develop a satisfactory network of social, communal and transport infrastructure over the past, which now needs to be adapted to become climate neutral (Negreiros and Falconer, 2021). In addition, it is important to implement the transition of the energy sector, considering the increasing availability of renewable energy, as an increase in the affordability of infrastructure for such forms of energy, in particular solar energy, which can be used by public institutions, private businesses and households. The energy transition of urban centres and their wider surroundings is an important item of the overall energy transition, more vulnerable than the transition in certain sectors of agricultural, industrial and transport activities (Droege, 2021). The transition of mobility also accounts for a very important aspect in the energy transition. The European Green Deal does not mention urban mobility as part of the green and energy transitions but reducing emissions from road transport in cities and urban regions is key to achieving the $90 \%$ reduction in transport emissions (Smeds and Cavoli, 2021).

The scenario for the development of the Šibenik Urban Area presented in this paper is based on the basic principles of the European Green Deal and, linked with other models of spatial development that are aligned with the objectives of the Deal. These activities include decarbonisation of the energy sector, circular management of space and buildings, creating energy efficiency, creating and enabling access to healthy food, and preserving biodiversity. 
In terms of stimulating the development of a particular space, the achievement of energy efficiency is particularly important. In 2020, the European Commission adopted a document entitled A Renovation Wave for Europe - greening our buildings, creating jobs, improving lives (COM(2020) 550), aimed at decarbonising residential and non-residential buildings, increasing their energy efficiency and creating new jobs in the construction sector. While energy renovation of all buildings would be encouraged, three measures stand out among the measures proposed in that document: tackling energy poverty and buildings with the worst energy performance, renovating public buildings (administrative, educational and healthcare) and decarbonising heating and cooling systems. The vision presented in this document presents Europe in 2030 as a place of a more resilient, greener and digitised society working in a circular system, where waste and emissions are reduced in all areas and energy needs are covered by reuse. A large part of households and other facilities will become electricity producers for their own purposes.

The circular economy is also one of the important models that accompanies the green and energy transitions. The circular economy could be defined as an economy where the value of products, materials and resources is maintained for as long as possible, and the amount of waste is reduced as much as possible (Milios, 2018). Cities and their regions could play an important role in the circular economy, as they consume $60-80 \%$ of the world's natural resources and generate about half of the world's total waste (Williams, 2021). Some European cities implement circular economy policy. For example, Amsterdam in 2020 adopted a document entitled Amsterdam Circular Strategy 2020-2025, defining three value chains that can be used for circular management: the organic and food waste system, consumer goods and the built environment. For the development of urban areas, in addition to circular management of various waste materials that are the product of housing, production or other social or economic activities, circular management of spaces and buildings is also very important, especially in areas where there are a number of brownfield locations.

In order to green transition of the urban environment in cities and their regions, different nature-based solutions can be used. Developed in European urban environments, the Nature based solutions (NBS) concept stands for 'living inspired solutions by, continuously supported by and using nature, which are designed to various societal challenges in a resource-efficient and adaptable manner and to provide simultaneously economic, social, and environmental benefits' (European Commission, 2015). The development of such solutions is usually associated with cities that are at a higher level of economic development (Fan et al., 2015). However, this does not mean that such solutions cannot be applied on a certain scale in urban regions where economic growth is slower. The term associated with NBS is green infrastructure, interconnected network of green spaces involving various areas ((semi-)natural areas, green corridors, green urban spaces and green roofs), and separate natural elements (e.g., individual trees) (Silveirinha de Olivera and Ward Thompson, 2015). The development of such a network can affect the increase in the level of health of urban populations, the increase in air quality of the city, the preservation of biodiversity and ecosystem services, as well as the development of an ecological and economic system for the management of green areas in urban regions (Sinnett et al., 2015).

The EU policy, which should also be considered when planning the development of urban areas, is a policy defined by the Farm to Fork strategy (European Commission, 2020). This strategy is aligned with the European Green Deal and its main purpose is to create a sustainable and resilient food system in the EU in which the population would have access to healthy food, affecting the increase in its quality of life, while minimising healthcare costs. In planning the development of urban areas, this strategy can be an incentive to revitalize agricultural and fishing production whose products can be effectively placed on the local urban market. This could lead to a strengthening of the agricultural products market at regional 
level and an increase in economic interactions and dynamics between urban centres and rural surroundings (Mora, 2018).

Urban areas in coastal zones should also base their development on sea valorisation. In this sense, one can talk about the development of the blue economy and the blue development. This development is also encouraged by the EU, and some of the main priorities raised in this area are the efficient use of resources in fisheries and the increase in the production and consumption of food from the sea, the improvement of the business environment for companies in maritime activities through institutional and infrastructure support, the promotion of research and innovation in the maritime economy, and the strengthening of human capacities (Kovačić et al., 2021). The combination of blue and green development models can open up additional perspectives for coastal areas that can be development generators for regional and national level through efficient use of all their resources.

\section{3. Šibenik Urban Area potential}

Šibenik Urban Area is an area that includes three local self-government units in the Republic of Croatia: the City of Šibenik, the City of Skradin and the Municipality of Bilice (Figure 1) with an area of $607 \mathrm{~km}^{2}$, where according to the estimate of the National Bureau of Statistics (CBS, 2020) in 2019 there were 49,890 inhabitants. In the urban settlement of Šibenik that year lived a more than two-thirds of the total population of the urban area. The urban area is defined by the procedure in accordance with the Law on Regional Development of the Republic of Croatia (OG 147/14; 123/17; 118/18), and the document establishing the strategic objectives of this area will be the Development Strategy of the Šibenik Urban Area.

Šibenik Urban Area is located in the northern central part of the Croatian region of Dalmatia and extends along the estuary of the Krka River into the Adriatic Sea and includes several islands. The area of the Šibenik Urban Area can be divided into three zones (Figure 1) depending on its natural, demographic and economic characteristics (Magaš, 2015). These are the coastal zone that is densely populated, highly touristificated, in which also other activities from the service and industrial sectors are concentrated. The hinterland zone includes a larger number of settlements with smaller populations that are experiencing negative demographic trends. This zone is mostly agrarian, but agricultural activities lose their function as a main income for the life of local population. The main development potential of the area is the attractive National Park Krka with karst river Krka which generates the development of tourism and accompanying activities. The third zone includes several islands, four of which are inhabited by more than 100 inhabitants. The island zone is characterized by highly aging population and out-migration. The leading activity of this area is tourism. 


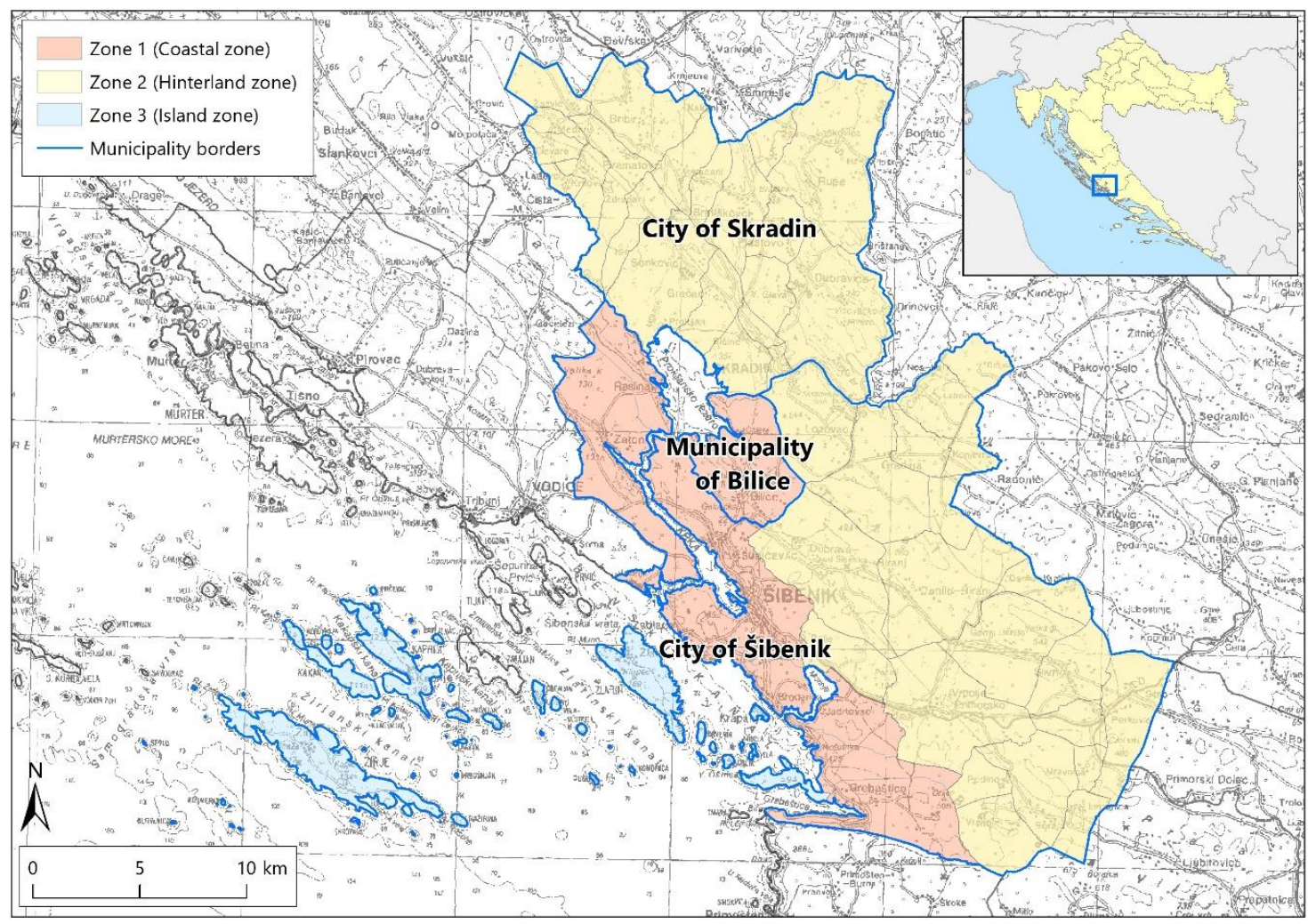

Figure 1. The location of the Šibenik Urban Area and the division into spatial zones. Source: Geoportal of SGA. Adapted by the authors.

In order to identify the basic challenges facing the Šibenik Urban Area and the basic potentials that can be used in its development, a two-step survey of the social, economic and infrastructural environment of the Šibenik Urban Area has been carried out. The first step involved an analysis of secondary sources on these three spatial aspects. Secondary sources were statistics issued by public institutions at the national level (Croatian Bureau of Statistics, ministries and public institutions dealing with various forms of space management), as well as at the local level (local self-government units, municipal and other publicly owned companies). The second part of the survey consisted of three courses of semi-structured interviews with representatives in the local public, private and civil sectors. Interviews were conducted between 2016 and 2021. Since this paper is based on extensive ongoing research, key results are listed in the shortest lines, without entering into the issue of each spatial phenomenon separately.

The society of the Šibenik Urban Area characterized the fact that almost the entire territory of the Area is depopulating, while the area with positive demographic trends is limited to a narrow coastal zone next to the urban settlement of Šibenik. Social infrastructure has been improving in recent years, especially through the development of cultural institutions and facilities in the urban settlement of Šibenik, and numerous educational institutions have been renovated and two higher education institutions have developed. On the other hand, it is important to note that the development of public institutions was also aimed at the area of the urbanized coastal zone, while settlements in the hinterland and on the islands have been losing their functions. This is especially evident in the closure or shortening of the working hours of regional primary schools, infirmaries, post offices or smaller private shops in smaller settlements. The population is ageing, hence there is an increasing need for social welfare services, which is putting increasing financial pressure on local units, which is being partially reduced by the implementation of a national scheme to employ hard-to-employ people in home assistance to elderly population, financed by EU funds. 
In the sector of the economy, there is a high level of orientation of the Šibenik Urban Area to tourism in all its zones. Šibenik in the second half of the $20^{\text {th }}$ century, at the time of state-managed economy, was a strong industrial centre with a developed metal processing and shipbuilding industry. After the 1990s, due to the deindustrialization process and the Homeland War that took place on the edges of the urban area, industrial production in Šibenik was significantly reduced. Production at some industrial plants in Šibenik has managed to survive to this day, albeit on a smaller scale compared to the situation in the past, which is primarily the result of private investments. A positive step towards diversifying the economy is the entrepreneurship promotion programmes implemented at national, regional and local level, which have enabled the development of entrepreneurial institutions and supporting infrastructure. However, all these institutions are concentrated in the coastal zone. The agrarian possibilities of the hinterland and islands have not been valorised to the full extent, partly due to the unpopularity of agriculture, especially for younger population, which has led to the age of the agricultural population being very high, and partly due to the relatively low level of familiarity of farmers and farmland owners with opportunities to improve agricultural activity through EU funds. It is a similar situation with the fisheries sector, where there are additional problems of lack of fish stock due to overfishing and lack of infrastructure for fish processing. Tourism is currently the activity that is experiencing the greatest prosperity in the Šibenik Urban Area. The number of tourist arrivals increased steadily in the time before the outbreak of the global COVID-19 pandemic, and accordingly significant investments took place in accommodation and catering infrastructure and in additional facilities that expanded the tourist offer from the original offer based solely on summer holiday (bathing) tourism. However, tourism is a highly seasonal activity that takes place almost exclusively in the summer part of the year. Due to the high concentration of the number of tourists during the summer period, there is a strong pressure on public, energy and transport infrastructure, which leads to conflicts between the local population. During the COVID-19 pandemic, there was a significant decrease in the number of tourist arrivals, which led to a decrease in general employment in the urban area, due to the fact that a large number of workers are employed in service sector activities related to tourism.

The main potential of the urban environment that makes the Šibenik Urban Area attractive for visiting, working and housing is the high quality of the natural karst landscape in several areas with varying degrees of nature protection, among which the Krka National Park stands out in particular, as well as the attractive agrarian landscape, especially in rural parts of the urban area. However, the emergence of natural risks, such as fires, droughts and torrents, often threatens the safety of the population and their property. In infrastructure terms, the fact that the urban area is well connected to the national network of motorways, and even to the international rail network, is of great importance, despite the poor quality of passenger rail transport in the southern part of Croatia. On the other hand, communal infrastructure, such as water, sewerage, energy and other infrastructure, needs to be more developed so that all residents of the urban area have a satisfactory level of availability of utilities. The specific challenge is also the existence of a number of brownfield locations resulting from the closure of industrial plants over the past 30 years, the rehabilitation of which needs to be carried out using the principle of circular space management or as part of the development of green infrastructure.

When planning spatial development and related physical interventions in the space, it is necessary to respect the development policies and plans of the EU, the development of the Šibenik Urban Area must be based on the implementation of the urban dimension of the policy defined by the European Green Deal. Also, since this is an area that is relatively less developed than the Croatian average, and much less than the EU average, in order to make development policy financially viable, the planned projects need to be adapted to provide funding from EU funds either through the European Green Deal, cohesion policy, 
agricultural policy or through the Recovery and Resilience Facility introduced to recover from the COVIDcrisis.

\section{Discussion - Šibenik Urban Area development scenario}

The scenario method is often applied in space planning in different world countries and at different spatial levels. Its advantage is integral observation of space, focus on states and processes at wide (national and international) spatial levels, as well as regional and local specificities in space, while at the same time giving its author the opportunity to view the future from several perspectives and create several parallel visions of the future (Radeljak Kaufmann, 2016). For this paper, the relevant type of scenario is a normative scenario, which is based on specific values that define the objectives that are intended to be achieved at some time (Rotmans et al., 2000). The main direction to be followed in the Šibenik Urban Area based on development needs and potential are demographic revitalization, economic diversification and green transition that together would enable sustainable and resilient development of the area.

After setting the basic objectives, the next step of developing a normative scenario concern defining the steps to be taken to meet certain objectives (Radeljak Kaufmann, 2016), for which it is necessary to highlight the basic development potentials and challenges, taking into account the specific characteristics of the space and offering certain solutions accordingly. This procedure is shown in Table 1 , which sets out the basic development potentials in society, economy, environment and infrastructure for each of the spatial units defined in the preceding chapter, and on this basis five different objectives were proposed to achieve defined objectives.

Table 1. Development challenges, potentials and proposed objectives by zones and development aspects for the Šibenik Urban Area. Source: Authors.

\begin{tabular}{|c|c|c|c|}
\hline \multirow[b]{2}{*}{ THEMATIC AREAS } & \multicolumn{3}{|c|}{ SPATIAL UNITS } \\
\hline & $\begin{array}{c}\text { ZONE } 1 \\
\text { (COAST ZONE) }\end{array}$ & $\begin{array}{c}\text { ZONE } 2 \\
\text { (HINTERLAND ZONE) }\end{array}$ & $\begin{array}{c}\text { ZONE } 3 \\
\text { (ISLAND ZONE) }\end{array}$ \\
\hline SOCIETY & $\begin{array}{l}\text { Challenge: concentration of } \\
\text { population and high cost of } \\
\text { construction } \\
\text { Potential: availability of various } \\
\text { social services } \\
\text { Specific objective: POST-COVID } \\
\text { REACTIVATION }\end{array}$ & $\begin{array}{l}\text { Challenge: population ageing } \\
\text { and out-migration } \\
\text { Potential: proximity to densely } \\
\text { populated urban centres on } \\
\text { the coast } \\
\text { Specific objective: POST-COVID } \\
\text { REACTIVATION }\end{array}$ & $\begin{array}{l}\text { Challenge: a highly ageing } \\
\text { population and loss of social } \\
\text { functions } \\
\text { Potential: the natural } \\
\text { attractiveness of the living } \\
\text { space } \\
\text { Specific objective: BLUE } \\
\text { DEVELOPMENT }\end{array}$ \\
\hline ECONOMY & $\begin{array}{l}\text { Challenge: high focus on } \\
\text { tourism and deindustrialisation } \\
\text { Potential: development of } \\
\text { entrepreneurial infrastructure } \\
\text { and support institutions } \\
\text { Specific objective: POST-COVID } \\
\text { REACTIVATION, GREEN } \\
\text { TRANSITION }\end{array}$ & $\begin{array}{l}\text { Challenge: the decline in the } \\
\text { importance of agriculture as an } \\
\text { activity } \\
\text { Potential: available agricultural } \\
\text { areas with a large coastal } \\
\text { market } \\
\text { Specific objective: POST-COVID } \\
\text { REACTIVATION, FARM-TO- } \\
\text { FORK }\end{array}$ & $\begin{array}{l}\text { Challenge: poor valorisation of } \\
\text { the sea as a development } \\
\text { resource } \\
\text { Potential: a long tradition of } \\
\text { activities aimed at the sea } \\
\text { Specific objective: BLUE } \\
\text { DEVELOPMENT }\end{array}$ \\
\hline $\begin{array}{l}\text { ENVIRONMENT } \\
\text { AND } \\
\text { INFRASTRUCTURE }\end{array}$ & $\begin{array}{l}\text { Challenge: tourism's pressure } \\
\text { on the environment and } \\
\text { infrastructure } \\
\text { Potential: valuable natural } \\
\text { landscape } \\
\text { Specific objective: GREEN } \\
\text { TRANSITION; MOBILE CITIZENS }\end{array}$ & $\begin{array}{l}\text { Challenge: underdeveloped } \\
\text { transport and utility } \\
\text { infrastructure network } \\
\text { Potential: developed network } \\
\text { of roads } \\
\text { Specific objective: GREEN } \\
\text { TRANSITION; MOBILE CITIZENS }\end{array}$ & $\begin{array}{l}\text { Challenge: lack of utility } \\
\text { infrastructure } \\
\text { Potential: application of new } \\
\text { technologies in infrastructure } \\
\text { development } \\
\text { Specific objective: BLUE } \\
\text { DEVELOPMENT }\end{array}$ \\
\hline
\end{tabular}


Locations in the urban area for the implementation of measures and activities foreseen by the objectives are presented on Figure 2 .

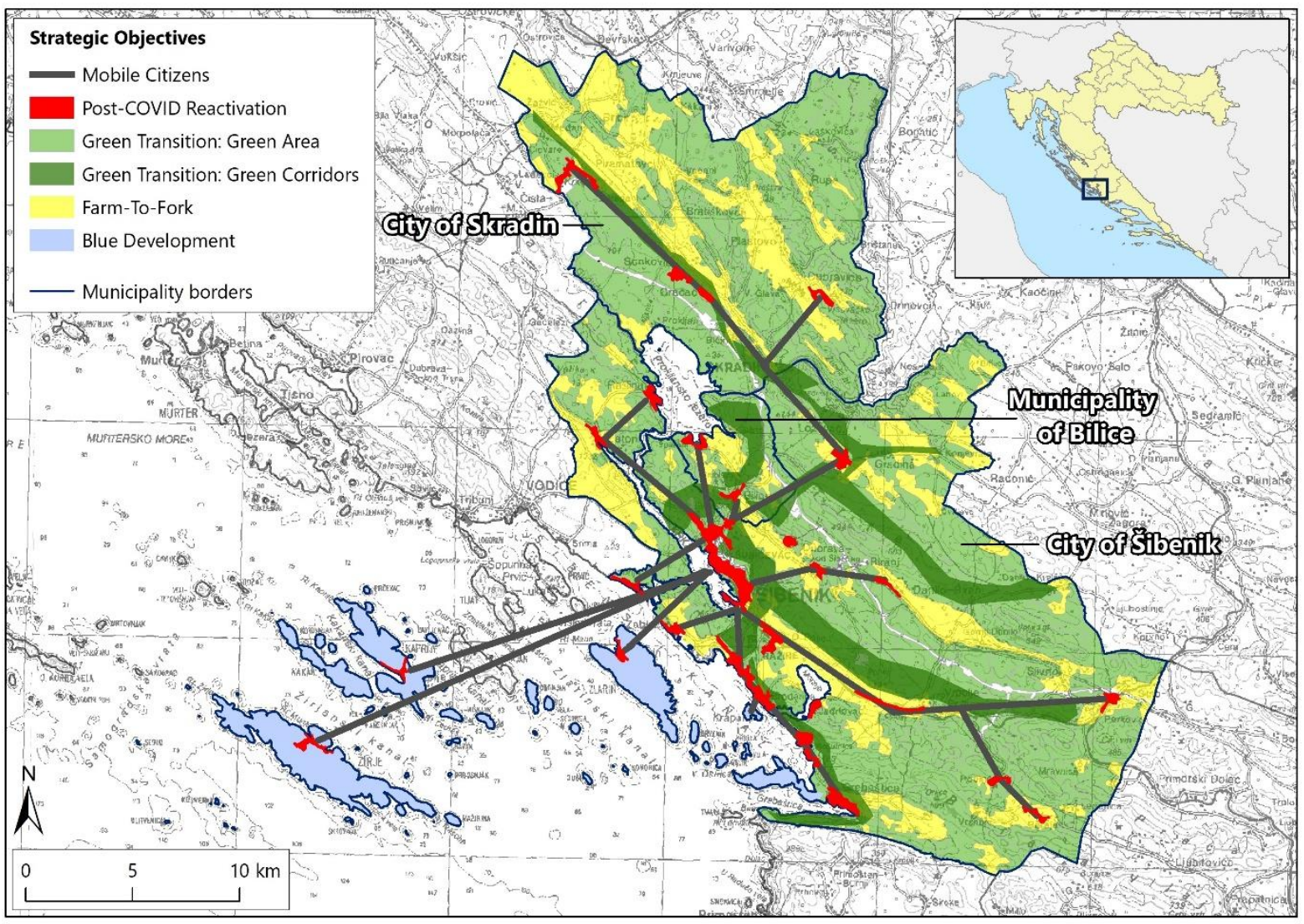

Figure 2. Sketch of the proposal of strategic objectives for the development of the Šibenik Urban Area. Source: Geoportal of SGA. Adapted by the authors.

The first objective, called Post-COVID reactivation, is intended for the coastal zone and the hinterland zone. It plans to implement measures that will enable optimization and improvement of social functions in the coastal zone, where they meet the needs of residents and tourists with their quality, and their revitalization in the hinterland zone, where lost functions could be replaced or supplemented by digital and mobile forms, while demographic development could be further encouraged by set of financial reliefs/benefits. In the development of the settlement, densification would be encouraged, which would prevent the city from overflowing into the surrounding unbuilt space. In addition, the economy will be affected by measures to diversify tourism and encourage entrepreneurship through stimulating the development of entrepreneurial infrastructure and institutions. In addition, this objective can also encourage the digitisation of public services and the development of innovative digital solutions, which can make this area known identifiably (and thus attract digital nomads, for example).

The economy also ought to be encouraged in the hinterland zone through the Farm-to-Fork objective measures, which would lead to the modernisation and revitalisation of the existing agrarian sector, the creation of a local value chain, where local agricultural products would be offered to customers on the local market, while linking agriculture to the tourism market by including local farmers' products in the tourism offer and developing rural tourism.

Green Transition measures should also be implemented in the coastal and hinterland zone, which would directly implement elements of the European Green Deal. This objective is aimed at three areas, decarbonising the society and economy, developing the green identity of the space and strengthening 
risk resilience. Decarbonisation of society would include the construction of green infrastructure and green corridors, and the energy renovation of existing facilities, thereby increasing the quality of life of the population, while also using circular space management solutions, giving brownfield locations a new social or economic purpose. Decarbonisation would also affect the economy, especially through encouraging emission reductions and circular space management, and traffic would be affected by the use of environmentally friendly vehicles and by encouraging environmentally neutral types of transport, such as cycling and walking. The green identity of the space would be strengthened by creating a planning framework and developing green infrastructure and corridors, implementing activities to preserve the natural values of the environment, improving waste management systems and adapting local infrastructure to preserve the environment. A special set of construction, technical and educational measures should strengthen the preparedness of the premises and the population to natural risks.

The fourth objective, Mobile Citizens, includes the development of mobility in urban area, the measures of which aim to encourage the development of green and modern public transport available in all parts of the coastal and hinterland zones, and to improve and revitalize any form of infrastructure. In this regard, it is necessary to build infrastructure for environmentally friendly vehicles (charging stations for electric vehicles). It is also especially important to exploit the potential of multimodal transport and to develop infrastructure for air transport on islands (helipads), allowing emergency services to be available on the islands.

A special objective, Blue Development, is planned for the island zone, which plans to economically revitalize the islands and increase the quality of life of the islands' population. The economic revitalisation of the island would include the promotion of traditional island activities, most notably fisheries, and would encourage the development of other activities on the islands provided that they are in line with green development policy or that activities are in a digital environment. Increasing the quality of the island population would include increasing the transport availability of the island and the green transition of the transport system on the islands, making utility infrastructure accessible using new solutions, such as ecological cesspools or desalinators, and encouraging the energy efficiency of public infrastructure and private facilities, as well as the development of social infrastructure on the islands. The emphasis in island development would also be on preserving the traditional island landscape and maintaining the cleanliness of the sea.

\section{Conclusion}

The three main directions of future urban development in Europe are densification, containment and regeneration (SUPER, 2020a), stemming from the planning policy of cities and urban regions in the EU. The European Green Deal has not yet defined its urban dimension and it is therefore necessary to think about how to create a comprehensive development policy based on existing good practices that will enable green, sustainable and resilient development in post-COVID time that will be simultaneously enforceable everywhere in Europe and yet take into account local specificities. This paper deals with the area of the Šibenik Urban Area, which is a very small territory, but contains several spatial units, each of which has its own developmental challenges and specificities. However, the green and digital transition of settlements, built spaces and public services, the revitalisation of agricultural areas for the local market, the valorisation and protection of green spaces and the establishment of green corridors, the strengthening of mobility and the blue development of coastal areas, as the main objectives to be adapted to local conditions and situation through priorities, measures and activities, can be the direction of future development of European Mediterranean cities seeking to better connect with their surroundings. 


\section{References}

A Renovation Wave for Europe - greening our buildings, creating jobs, improving lives COM(2020) 550. European Commission. Brussels

Abdullah, H. (2021) 'Introduction' in Abdullah, H. (ed.) Towards a European Green Deal: The urban dimension of the EU's sustainable growth strategy. Barcelona: CIDOB Editions, pp. 11-23

Amsterdam Circular Strategy 2020-2025 (2020). City of Amsterdam. Amsterdam

Cities in Statistics (2020). Central Bureau of Statistics. Zagreb

de Gregorio Hurtado, S. (2021) 'A Green Deal for the Urban Age: A New Role for Cities in EU Climate Action' in Abdullah, H. (ed.) Towards a European Green Deal: The urban dimension of the EU's sustainable growth strategy. Barcelona: CIDOB Editions, pp. 27-38

Droege, P. (2021) 'Beyond Green, Beyond the Deal: Towards the Renewable City' in Abdullah, H. (ed.) Towards a European Green Deal: The urban dimension of the EU's sustainable growth strategy. Barcelona: CIDOB Editions, pp. 63-74

European Green Deal COM(2019) 640. European Commission. Brussels

Fan, P., Ouyang, Z., Basnou, C., Pino, J., Park, H. and Chen, J. (2017) 'Nature-based solutions for urban landscapes under post-industrialization and globalization: Barcelona versus Shangai', Environmental Research, 156, p272-283

Farm to Fork Strategy: For a fair, healthy and environmentally-friendly food system. (2020) European Commission. Brussels

Geoportal of State Geodetic Administration. (2020) State Geodetic Administration of the Republic of Croatia (SGA) [online]. Available at: https://geoportal.dgu.hr/ (Accessed: 1 September 2021)

Hall, P. and Tewdwr-Jones, M. (2010) Urban and Regional Planning. 5th edn. London and New York: Routledge

Kovačić, M., Perinić, L. and Kerčević, S. (2021) 'Greening the Blue Economy as an Incentive to Sustainable Development of Primorje-Gorski Kotar County', Multidisciplinary Scientific Journal of Maritime Research, 35, p159-169

Law on Regional Development of the Republic of Croatia, OG 147/14; 123/17; 118/18

Magaš, D. (2015) The Geography of Croatia. 1st edn. Zadar, Samobor: University of Zadar, Meridijani

Milios, L. (2018) 'Advancing to a Circular Economy: three essential ingredients for a comprehensive policy mix', Sustainability Science, 13, p861-878

Mora, O. (2018) 'Scenarios of Land Use and Food Security in 2050' in Le Mouël, C., de Lattre-Gasquet, M. and Mora, O. (eds.) Land Use and Food Security in 2050: a Narrow Road. Versailles: Éditions Quae, pp. 206-246

Negreiros, P. and Falconer, A. (2021) 'Financing the Green Transition of European Cities' in Abdullah, H. (ed.) Towards a European Green Deal: The urban dimension of the EU's sustainable growth strategy. Barcelona: CIDOB Editions, pp. 49-59

Ossewaarde, M. and Ossewaarde-Lowtoo, R. (2020) 'The EU's Green Deal: A Third Alternative to Green Growth and Degrowth?', Sustainability, 12(23) [online]. Available at: https://www.mdpi.com/2071-1050/12/23/9825 (Accessed: 30 August 2021) 
Priebs, A. (2019) Die Stadtregion: Planung - Politik - Management. 1st edn. Stuttgart: Verlag Eugen Ulmer

Radeljak Kaufmann, P. (2016) 'Scenario Method in Spatial Research and Planning', Croatian Geographic Bulletin, 78(1), p47-71

Rotmans, J., van Asselt, M., Anastasi, C., Greeuw, S., Mellors, J., Peters, S., Rothman, D., Rijkens, N. (2000) 'Visions for a sustainable Europe', Futures, 32 (9-10), p809-831

Silveirinha de Olivera, E. and Ward Thompson, C. (2015) 'Green infrastructure and health' in Sinnet, D., Smith, N. and Burgess, S. (eds.) Handbook on Green Infrastructure: Planning, Design and Implementation. Cheltenham, Northampton: Edward Elgar Publishing, pp. 11-29

Sinnet, D., Smith, N. and Burgess, S. (2015) 'Introduction' in Sinnet, D., Smith, N. and Burgess, S. (eds.) Handbook on Green Infrastructure: Planning, Design and Implementation. Cheltenham, Northampton: Edward Elgar Publishing, pp. 11-29

Smeds, E. and Cavoli C. (2021) 'Pathways for Accelerating Transitions Towards Sustainable Mobility in European Cities' in Abdullah, H. (ed.) Towards a European Green Deal: The urban dimension of the EU's sustainable growth strategy. Barcelona: CIDOB Editions, pp. 75-91

SUPER - Sustainable Urbanisation and Land Use Practices in European Regions: A Guide to Sustainable Urbanisation and Land Use. (2020a) ESPON [online]. Available at: https://www.espon.eu/sites/default/files/attachments/2020_ESPON_SUPER_Guide_final_A4_scr eenview.pdf (Accessed: 1 September 2021)

Towards an EU research and innovation policy agenda for nature-based solutions \& re-naturing cities: Final Report the Horizon 2020 Expert Group. (2015) European Commission. Directorate-general for research and innovation-climate action, environment, resource efficiency and raw materials Luxembourg

Williams, J. (2021) 'Circular Cities: What Are the Benefits of Circular Development', Sustainability, 13(10) [online]. Available at: https://www.mdpi.com/2071-1050/13/10/5725 (Accessed: 30 August 2021) 